RUSA

\section{Achievement Awards 2019}

For questions about RUSA Awards, contact Shuntai Sykes, Membership and Programs Specialist, ssykes@ala.org.
RUSA and its Sections are home to many knowledgeable and influential librarians who place libraries users at the center of their work. Each year members of RUSA's Achievement Awards honor the most outstanding people, institutions, and projects in the field of reference and user services. This year's selections were made possible with the hard work of our many superb committee volunteers, the people who took the time to nominate awardees, and the vendors who sponsored the awards. For each of the awards the winner is listed with a brief summary of why they were chosen. Further information about the winners is available in the RUSA Update press releases http://www.rusaupdate.org/category /news/awards-news/. The nomination period for the 2020 Awards opens in October 2019. See the individual award websites at http://www.rusaupdate.org/awards/ for further information.-Editor

\section{BRASS AWARDS}

The BRASS SimplyMap Student Travel Award enables a student enrolled in an ALA-accredited master's program to attend an ALA Annual Conference. The award is given to a candidate who has demonstrated an interest in pursuing a career as a business reference librarian and has the potential to be a leader.

Zoeanna Mayhook, MLIS student at the University of Washington. She currently works as a Graduate Reference Specialist at the University of Washington Tacoma Library and as a Legal Investigator and Researcher for Friedman Rubin Law Firm in Bremerton, Washington. Mayhook also serves as the Publicity Officer for the University of Washington Chapter of the Special Library Association (SLA-UW). While pursuing her MLIS at the University of Washington, Mayhook has completed coursework in Business Information Resources, Government Publications, and Academic Librarianship.

Sponsored by SimplyAnalytics/SimplyMap (Geographic Research)

The BRASS Global Financial Data Academic Business Librarianship Travel Award is awarded to a librarian new to the field of academic business librarianship to support attendance to the ALA Annual Conference.

Abigail Morgan, Social Sciences and Business Librarian at Miami University. She is currently the liaison to the Economics, Education, Juvenile Literature, and Teacher Education faculty and shares responsibility for Marketing. Morgan is a new (and enthusiastic) member of BRASS and is also a member of the ALA Games and Gaming Round 


\section{FROM COMMITTEES OF RUSA}

Table. She is looking forward to attending her first ALA annual conference.

Sponsored by Global Financial Data

The BRASS Morningstar Public Librarian Support Award is awarded to a business reference public librarian to support travel costs to attend the ALA Annual Conference.

Amilcar Perez, Adult Services Librarian at Forest Park Public Library. Perez's main areas of focus are to increase visibility to the business community, build digital literacy, promote job and career development, and design assessment methods to identify gaps between community needs and programming. He has made distinctive impact on a new series at FPPL, "Explore Forest Park," which highlights local businesses.

Sponsored by Morningstar

The BRASS Emerald Research Grant Award is given to support research in business librarianship.

Amanda Click, Business Librarian, American University, along with her research teammates Claire Wiley, Research and Instruction Librarian, Belmont University, and Meggan Houlihan, Coordinator of Library Instruction and Student Programs, New York University Abu Dhabi. The winning project was "The Framework in Business Information Literacy: A Mixed Methods Study." The study will include a systematic review, a survey, and focus groups with the goal of identifying best practices and new ideas for teaching as well as increasing the value of the Framework for business librarians.

Sponsored by Emerald Publishing

The BRASS Mergent, by FTSE Russell, Excellence in Business Librarianship Award recognizes an individual who has distinguished him or herself in the field of business librarianship.

Todd Hines, Manager, Research and Discovery and Business Research Librarian, Stanford University GSB Library. Hines received this award for his distinguished achievement and service in business librarianship; for his work as founder of the Journal of Business and Finance database review column; and for his recognized excellence in mentoring both new and seasoned librarians. Hines has been a leader, a contributing committee member, and a long-time member of RUSA and BRASS.

Sponsored by Mergent, by FTSE Russell

\section{COLLECTION DEVELOPMENT AND}

EVALUATION SECTION (CODES)

The Louis Shores Award recognizes excellence in reviewing of books or other materials for libraries.

Donna Seaman, Adult Books Editor, Booklist. Donna Seaman's contributions to the field of book reviewing have been undeniably outstanding in both breadth and depth. The many thousands of reviews she has written demonstrate her deep knowledge and experience. Her work as an editor of book reviews has also been immensely valuable to innumerable Booklist readers, and the author interviews she has aired on WLUW's Open Books Radio have brought her passion for books to the Chicago public as well.

EMERGING TECHNOLOGIES SECTION (ETS)

The ETS Achievement Recognition Award is presented in recognition of excellence in service to the ETS section.

Donna Brearcliffe, Acting Head, Humanities and Social Sciences Section, Researcher and Reference Services Division of the Library of Congress. Brearcliffe served as Chair of ETS shortly after the section changed its name from MARS. She advocated strongly for completing that transition and embracing the opportunities that could come from firmly focusing the section around emerging technologies.

\section{HISTORY SECTION (HS)}

The Genealogy / History Achievement Award was established to encourage, recognize, and commend professional achievement in genealogical reference and research librarianship.

Mary Lovell Swetnam, Special Collections Librarian, Virginia Beach Public Library. Her passion for librarianship, for the special collections she manages, and in serving the Virginia Beach community, is as evident today as it has been for the more than three decades she has worked in libraries. Swetnam received this award for her enthusiastic service and commitment in helping her patrons with genealogy and local history research; for her dedication in helping preserve the local history of her community through the archival record.

Sponsored by ProQuest

The Gale Cengage Learning History Research and Innovation Award is presented annually to a librarian to facilitate and further research relating to history and history librarianship.

Jennifer Brannock, Curator of Rare Books and Mississippiana, University of Southern Mississippi Libraries. Ms. Brannock was selected for her innovative historical research in support of her project "Con Sellers, Masculinity, and the Publishing Industry: Lowbrow Publications in Midcentury America."

Sponsored by Gale Cengage Learning

\section{SHARING AND TRANSFORMING ACCESS TO RESOURCES SECTION (STARS)}

The Atlas-Systems Mentoring Award is awarded to two library practitioner new to the field of interlibrary loan, document delivery, or electronic reserves, and supports travel expenses for the ALA Annual Conference. 
Pearl G. Adzei-Stonnes, Public Services, Acquisitions and Interlibrary Loan Librarian at Virginia Union University. Adzei-Stonnes was chosen as the winner of the STARS Atlas Systems Mentoring Award because the essay submitted had an overall theme of leadership.

Guerda Baucicaut, Inter Library Loan and Reserves Specialist at the City University of New York. Baucicaut understands the importance of networking and actively seeks out opportunities to learn from others in the profession. Her essay also emphasized the need for continuous learning for librarians and users alike.

Sponsored by Atlas Systems

The Virginia Boucher-OCLC Distinguished Interlibrary Loan Librarian Award is given to a librarian for outstanding professional achievement, leadership, and contributions in interlibrary loan and document delivery.

Zack Lane, Head of Delivery Services, Butler Library, Columbia University Libraries. Lane was nominated by three of his peers for his efforts to use data to demonstrate that common lending practices were wasting staff time and doing a disservice to library users. His solid evidence makes a case for setting aside old ways of thinking and focusing instead on adding value to every transaction for every library user. Lane's analysis of Columbia University's lending and borrowing led him to change their policies, which led to a widespread and increasing adoption of a 16-week loan period.

Sponsored by OCLC/WorldCat

\section{REFERENCE AND USER SERVICES (RUSA)}

The John Sessions Memorial Award is presented to a library or library system in recognition of significant efforts to work with the labor community.

The Iowa Labor Collection and Iowa Labor History Oral Project, State Historical Society of Iowa. The Iowa Labor Collection is widely regarded as one of the most comprehensive labor history collections in the world, and ILHOP is one of the only large-scale oral history projects initiated and funded by labor unions themselves. ILHOP and the Iowa Labor Collection represent an enduring partnership between Iowa labor unions and the State Historical Society.

Sponsored by the Department for Professional Employees, AFL-CIO

NoveList's Margaret E. Monroe Library Adult Services Award recognizes a librarian who has made significant contributions to library adult services.

Nicolette Warisse Sosulski, Business Librarian at Portage District Library. Sosulski developed innovative modes of service in areas including business librarianship, the reference interview, virtual librarianship, assistance for those with medical and insurance questions; and instructional librarianship, then shared these methods with colleagues and students through courses, presentations, and articles.
Her columns "A Reference for That" for RUSQ and "Real-Life Reference" for Booklist have provided insight, humor, and compassion for professional colleagues. She has also supported library publications behind the scenes, serving on editorial boards and as a column editor for RUSQ.

Sponsored by NovelList

The ReferenceUSA Award for Excellence in Reference and Adult Services recognizes a library or library system for developing an imaginative and unique resource to meet patrons' reference needs.

Heather Holtzman, Reference and Instruction Librarian at St. Petersburg College. Their Speed Dating project is an interactive series of instructional and supplementary materials that will be used to educate students and faculty on the different types of databases offered by St. Petersburg College. Holtzman strives to learn new things and to help her community. These efforts have included serving as an ALA member, volunteering in the public sector at Palm Harbor Library, and coordinating outreach opportunities in the greater community. At SPC, Holtzman has served on the Career and Academic Communities Leadership Triad Team (Business), the SPC Reads Committee, and implemented the weekly writing workshop "Hard Times" that created a safe and collaborative support network for students to express themselves through writing.

Paula Knipp, Reference and Instruction librarian at St. Petersburg College. Knipp currently serves as co-chair of the SPC Reads Committee (One Book One College program) and as Secretary of the SPC Alumni Association Board of Directors. Knipp is a member of the Florida Library Association's Legislative and Advocacy Committee and has previously worked on the FLA Personnel and Recruitment Committee. Passionate about library services, Paula and has helped secure grants for the center's STEAMworks technology lab as well as a grant to gamify library instruction sessions called Not-so-trivial pursuit: Incorporating games and active learning into library instruction.

Kassie Sherman, Library Services Paraprofessional at St. Petersburg College's Tarpon Springs Campus. As a current graduate student in the Masters in Library and Information Science program at the University of South Florida, Sherman combines her current studies with practical, on-thejob library experience to further develop her instructional skills. Sherman is a member of the Leepa-Rattner Museum of Art Education and Outreach Committee which focuses on creating educational opportunities with the museum for St. Petersburg College students as well encourages outreach to the community at large.

Sponsored by Reference USA

The Isadore Gilbert Mudge Award, RUSA's highest honor, is given to an individual who has made a distinguished contribution to reference librarianship.

Kay Ann Cassell, Professor Emerita, School of Communication and Information, Rutgers University. Cassell has 


\section{FROM COMMITTEES OF RUSA}

been a dedicated member and contributor to state, national, and international professional organizations-including the Presidency of RUSA, a decade on the ALA Council, chair of the ALA Publications Committee, the ALA Membership Committee, SRRT and myriad of feminist activities. Cassell has a distinguished career as reference librarian and reference educator, teaching emerging models in a constantly changing world; her scholarship as co-author of the leading textbook on reference, now in its fourth edition; and her active role in professional library organizations at the state, national, and international levels are works that continue the legacy of scholar librarians begun by Isadore Gilbert Mudge at Columbia University so many years ago.

Sponsored by Credo Reference 